\title{
Article
}

\section{Electrochemically initiated release: exploring new modalities for controlled drug release}

Devine, Amy, Hegarty, Catherine, Casimero, Charnete, Molyneaux, Rebecca Louise, Smith, Robert B, Cardosi, Marco F. and Davis, James

Available at http://clok.uclan.ac.uk/31815/

Devine, Amy, Hegarty, Catherine, Casimero, Charnete, Molyneaux, Rebecca Louise, Smith, Robert B ORCID: 0000-0002-2829-5360, Cardosi, Marco F. and Davis, James (2020) Electrochemically initiated release: exploring new modalities for controlled drug release. Journal of Electroanalytical Chemistry . ISSN 1572-6657

It is advisable to refer to the publisher's version if you intend to cite from the work. http://dx.doi.org/10.1016/j.jelechem.2020.113926

For more information about UCLan's research in this area go to

http://www.uclan.ac.uk/researchgroups/ and search for <name of research Group>.

For information about Research generally at UCLan please go to http://www.uclan.ac.uk/research/

All outputs in CLoK are protected by Intellectual Property Rights law, including Copyright law. Copyright, IPR and Moral Rights for the works on this site are retained by the individual authors and/or other copyright owners. Terms and conditions for use of this material are defined in the policies page. 
Title: Synthesis of naphthoquinone-aminophenol redox systems for electrochemically activated drug delivery

Authors: Rebecca Louise. Molyneaux ${ }^{1}$ and Robert B. Smith ${ }^{2}$

Affiliations:

1. Chemistry, Physical Sciences and Computing, University of Central Lancashire, Preston, PR1 2HE, UK

${ }^{2}$ UCLan's Research Centre for Smart Materials, University of Central Lancashire, Preston, PR1 2HE, UK

Contact email: RBSmith@uclan.ac.uk

\begin{abstract}
A series of naphthoquinone-aminophenol derivatives have been synthesized on the basis that their conjugation with a suitable drug candidate could provide a means through which the latter could be released upon the imposition of an appropriate oxidation potential. The approach is based on a three component assembly in which the naphthoquinone redox centre serves as a reporter unit allowing electrochemical interrogation without release of the drug. The central aminophenol serves as the tether to which the drug is linked via an ether bond. Upon oxidation of the aminophenol - ether component, transition of the latter to quinone imine results in the release of the drug. Substitution of the aminophenol component with 1,4-methoxyaniline yields a derivative which, upon oxidation, results in the ejection of the methoxy as methanol. The methoxy functional group in this case serves as the model drug component. The paper describes the preparation, purification and characterization of the redox tethers.
\end{abstract}

- Simple stepwise preparation of substituted Benzo[g]pteridine-2,4(3H,10H)-diones

- Dual redox center analogues

- Oxidation ether linkage resulting in transformation back to quinone imine

Add up to 3 bullet points, highlighting the customization rather than the steps of the procedure. Highlight how it differs/which advantage it offers over pre-existing methods.]

Keywords: Redox Tether; Controlled Drug Release; Quinone

Specifications Table [please fill in right-hand column of the table below]

\begin{tabular}{|l|l|}
\hline Subject area & $\bullet$ Chemical Engineering \\
\hline More specific subject area & Synthetic Chemistry/Electrochemistry \\
\hline Method name & Synthesis of Substituted Benzo[g]pteridine-2,4(3H,1OH)-dione \\
\hline $\begin{array}{l}\text { Name and reference of } \\
\text { original method }\end{array}$ & N/A \\
\hline Resource availability & N/A \\
\hline
\end{tabular}




\section{Method details}

The rationale behind the synthesis of the substituted naphthoquinone-aminophenol derivatives lies in the oxidative transformation of aminophenol component. Where the hydroxyl group of the latter is converted to an ether link through conjugation with a model drug component, electrochemical oxidation leads to the cleavage of the bond resulting in the ejection of the drug as indicated in Figure 1.
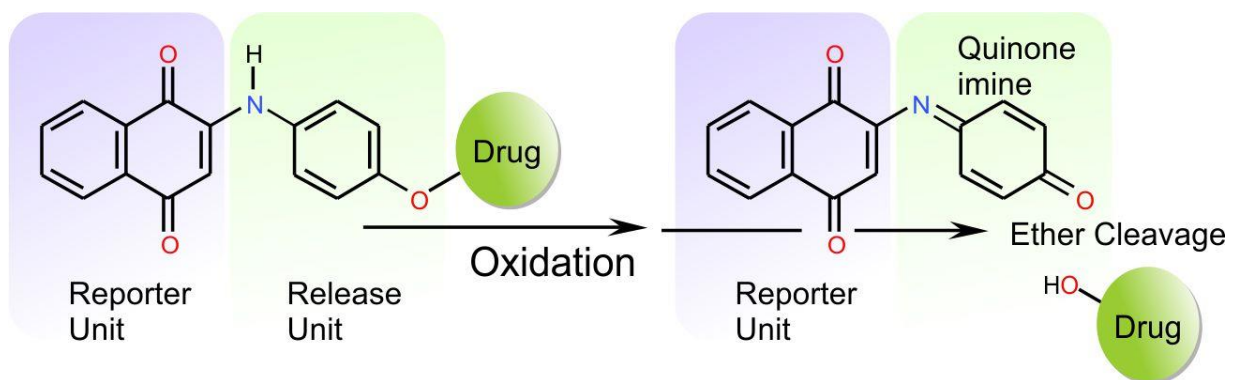

Figure 1. Oxidative pathway leading to the release of the tethered drug.

\section{Synthesis}

The synthesis of the substituted 1,4-napthoquinone derivatives was accomplished via a Michael addition as shown in Scheme 1 below. To expand, the 1,4-napthoquinone was dissolved in warm methanol and the aromatic amine was added in one portion. Continuous stirring was employed for one hour at room temperature and the solid precipitate produced was isolated at the pump. Yields were poor to moderate. Purification of the compound (if required) was accomplished, by heating the newly prepared solid in methanol and isolating then isolating at the pump.<smiles>[R]c1cccc(N)c1</smiles><smiles>CCCCCCCOC</smiles><smiles>[R]c1ccc(NC2=CC(=O)c3ccccc3C2=O)cc1</smiles>

$\mathrm{R}=3-\mathrm{OH}, 4-\mathrm{OH}, 4-\mathrm{OMe}$ and $4-\mathrm{NH}_{2}$

\section{Scheme 1 - Synthesis of substituted naphthoquinones}




\section{Experimental}

\section{General Information}

All chemicals were obtained from Sigma-Aldrich, were the highest grade available and were used without further purification. NMR spectra were recorded on a Bruker Fourier $300(300 \mathrm{MHz})$ spectrometer. Chemical shifts are reported in ppm relative to solvent residual ( ${ }^{1} \mathrm{H} N M R \mathrm{~d}_{6}-\mathrm{DMSO}$, $2.500 \mathrm{ppm}$ and ${ }^{13} \mathrm{C}$ NMR d $\mathrm{d}_{6}$-DMSO, $\left.39.520 \mathrm{ppm}\right)$. Coupling constants are reported in $\mathrm{Hertz}(\mathrm{Hz})$ and are rounded to the nearest $0.5 \mathrm{~Hz}$. Multiplicities are reported as singlets (s), doublets (d) and triplets $(\mathrm{t}$ ) or a combination of these, peaks that appeared broad due to either $\mathrm{H}$-bonding or restricted rotation are prefixed as broad (br). Low resolution mass spectra were recorded on a Finnigan $^{\mathrm{TM}}$ LCQ $^{\mathrm{TM}}$ Advantage MAX in ESI mode. Infra-red spectra $\left(1800-800 \mathrm{~cm}^{-1}\right)$ were recorded on a Perkin Elmer Spectrum RX 1 with a Specac Golden Gate ${ }^{\mathrm{TM}}$ ATR accessory and values are quoted in wavenumbers.

\section{2-(3-Aminophenol)-1,4-napthoquinone}<smiles>O=C1C=C(Nc2cccc(O)c2)C(=O)c2ccccc21</smiles>

To a round bottom flask containing 1,4-naphthoquinone $(1.58 \mathrm{~g}, 10 \mathrm{mmol})$ was added methanol $(50 \mathrm{~mL})$ and the mixture was warmed until all the 1,4-naphthoquinone had dissolved. With constant stirring, 3-aminophenol $(1.09 \mathrm{~g}, 10 \mathrm{mmol})$ was added in one portion and the reaction was left to stir at room temperature of 1 hour to yield a deep red precipitate. The precipitate was isolated at the pump and washed with cold methanol to yield 2-(3-aminophenol)-1,4napthoquinone $(0.63 \mathrm{~g}, 25 \%)$ as a deep red solid.

${ }^{1} \mathrm{H}$ NMR (300 MHz, DMSO-d 6 ) $\delta 9.67(\mathrm{~s}, 1 \mathrm{H}), 9.16(\mathrm{~s}, 1 \mathrm{H}), 8.06$ (dd, J = 7.5, $\left.1.5 \mathrm{~Hz}, 1 \mathrm{H}\right), 7.95$ (dd, J $=7.6,1.5 \mathrm{~Hz}, 1 \mathrm{H}), 7.86(\mathrm{td}, \mathrm{J}=7.5,1.5 \mathrm{~Hz}, 1 \mathrm{H}), 7.79(\mathrm{td}, \mathrm{J}=7.4,1.6 \mathrm{~Hz}, 1 \mathrm{H}), 7.23(\mathrm{t}, \mathrm{J}=8.1 \mathrm{~Hz}, 1 \mathrm{H})$, $6.90-6.76(\mathrm{~m}, 2 \mathrm{H}), 6.62(\mathrm{~d}, \mathrm{~J}=8.9 \mathrm{~Hz}, 1 \mathrm{H}), 6.16(\mathrm{~s}, 1 \mathrm{H}) .{ }^{13} \mathrm{C}$ NMR $(75 \mathrm{MHz}, \mathrm{DMSO}) \delta 183.03$, $182.03,158.47,146.48,139.52,135.34,133.09,133.01,130.91,130.48,126.60,125.72,114.68$, $112.83,110.74,102.68$. LCMS (ESI): $m / z$ 265.06.

\section{2-(4-Aminophenol)-1,4-napthoquinone}<smiles>O=C1C=C(Nc2ccc(O)cc2)C(=O)c2ccccc21</smiles>

To a round bottom flask containing 1,4-naphthoquinone $(1.58 \mathrm{~g}, 10 \mathrm{mmol})$ was added methanol $(50 \mathrm{~mL})$ and the mixture was warmed until all the 1,4-naphthoquinone had dissolved. With constant stirring, 4-aminophenol $(1.09 \mathrm{~g}, 10 \mathrm{mmol})$ was added in one portion and the reaction was left to stir at room temperature of 1 hour to yield a deep red precipitate. The precipitate was isolated at the pump and washed with cold methanol to yield 2-(4-aminophenol)-1,4napthoquinone (1.06 $\mathrm{g}, 42 \%)$ as a deep red solid. 
${ }^{1} \mathrm{H}$ NMR (300 MHz, DMSO-d $)$ ) $9.61(\mathrm{~s}, 1 \mathrm{H}), 9.11(\mathrm{~s}, 1 \mathrm{H}), 8.05$ (dd, J = 7.6, $\left.1.5 \mathrm{~Hz}, 1 \mathrm{H}\right), 7.94$ (dd, J $=7.6,1.5 \mathrm{~Hz}, 1 \mathrm{H}), 7.85(\mathrm{td}, \mathrm{J}=7.4,1.4 \mathrm{~Hz}, 1 \mathrm{H}), 7.77(\mathrm{td}, \mathrm{J}=7.5,1.5 \mathrm{~Hz}, 1 \mathrm{H}), 7.23-7.12(\mathrm{~m}, 2 \mathrm{H})$, $6.90-6.78(\mathrm{~m}, 2 \mathrm{H}), 5.88(\mathrm{~s}, 1 \mathrm{H}) .{ }^{13} \mathrm{C} \mathrm{NMR}(75 \mathrm{MHz}$, DMSO) $\delta 182.55,182.16,155.76,147.50$, $135.33,133.26,132.87,130.88,129.38,126.49,126.26,125.70,116.23,101.16$. LCMS (ESI): $\mathrm{m} / \mathrm{z}$ 264.95.

\section{2-(4-Methoxyanilino)-1,4-naphthoquinone}

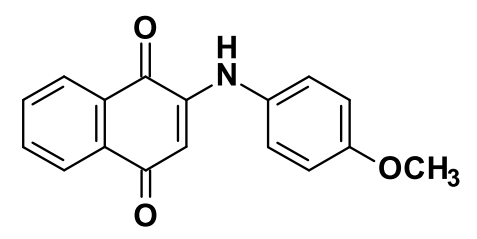

To a round bottom flask containing 1,4-naphthoquinone $(1.58 \mathrm{~g}, 10 \mathrm{mmol})$ was added methanol $(50 \mathrm{~mL})$ and the mixture was warmed until all the 1,4-naphthoquinone had dissolved. With constant stirring, $p$-anisidine $(1.23 \mathrm{~g}, 10 \mathrm{mmol})$ was added in one portion and the reaction was left to stir at room temperature of 1 hour to yield a deep red precipitate. The precipitate was isolated at the pump and washed with cold methanol $(50 \mathrm{~mL})$ to yield 2-(4-methoxyanilino)-1,4naphthoquinone $(1.44 \mathrm{~g}, 54 \%)$ as a deep purple solid.

${ }^{1} \mathrm{H}$ NMR (300 MHz, DMSO-d 6 ) $\delta 9.20(\mathrm{~s}, 1 \mathrm{H}$ ), 8.05 (dd, J = 7.5, $1.5 \mathrm{~Hz}, 1 \mathrm{H}$ ), 7.94 (dd, J = 7.6, 1.5 $\mathrm{Hz}, 1 \mathrm{H}), 7.85(\mathrm{td}, \mathrm{J}=7.5,1.5 \mathrm{~Hz}, 1 \mathrm{H}), 7.77(\mathrm{td}, \mathrm{J}=7.5,1.6 \mathrm{~Hz}, 1 \mathrm{H}), 7.30(\mathrm{~d}, \mathrm{~J}=9.0 \mathrm{~Hz}, 2 \mathrm{H}), 7.02$ $(\mathrm{d}, \mathrm{J}=8.9 \mathrm{~Hz}, 2 \mathrm{H}), 5.93(\mathrm{~s}, 1 \mathrm{H}), 3.78(\mathrm{~s}, 3 \mathrm{H}) .{ }^{13} \mathrm{C}$ NMR $(75 \mathrm{MHz}, \mathrm{DMSO}) \delta 182.68,182.10,157.35$, $147.31,135.32$, 133.18, 132.92, 131.03, 130.87, 126.51, 126.05, 125.70, 114.95, 101.45, 55.75. LCMS (ESI): $m / z 279.51$.

\section{2-(4-Aminoanilino)-1,4-naphthoquinone}<smiles>Nc1ccc(NC2=CC(=O)c3ccccc3C2=O)cc1</smiles>

To a round bottom flask containing 1,4-naphthoquinone $(1.58 \mathrm{~g}, 10 \mathrm{mmol})$ was added methanol $(50 \mathrm{~mL})$ and the mixture was warmed until all the 1,4-naphthoquinone had dissolved. With constant stirring, p-phenylenediamine $(1.09 \mathrm{~g}, 10 \mathrm{mmol})$ was added in one portion and the reaction was left to stir at room temperature of 1 hour to yield a deep red precipitate. The precipitate was isolated at the pump and washed with cold methanol $(50 \mathrm{~mL})$ to yield 2-(4aminoanilino)-1,4-naphthoquinone $(0.98 \mathrm{~g}, 39 \%)$ as a black solid.

${ }^{1} \mathrm{H} \mathrm{NMR}\left(300 \mathrm{MHz}, \mathrm{DMSO}-\mathrm{d}_{6}\right) \delta 9.02(\mathrm{~s}, 1 \mathrm{H}), 8.04(\mathrm{dd}, \mathrm{J}=7.6,1.4 \mathrm{~Hz}, 1 \mathrm{H}), 7.93$ (dd, J = 7.7, 1.4 $\mathrm{Hz}, 1 \mathrm{H}), 7.84(\mathrm{td}, \mathrm{J}=7.5,1.5 \mathrm{~Hz}, 1 \mathrm{H}), 7.75(\mathrm{td}, \mathrm{J}=7.4,1.5 \mathrm{~Hz}, 1 \mathrm{H}), 7.02(\mathrm{~d}, \mathrm{~J}=8.7 \mathrm{~Hz}, 2 \mathrm{H}), 6.62$ $(\mathrm{d}, \mathrm{J}=8.7 \mathrm{~Hz}, 2 \mathrm{H}), 5.85(\mathrm{~s}, 1 \mathrm{H}), 5.26(\mathrm{~s}, 2 \mathrm{H}) .{ }^{13} \mathrm{C} \mathrm{NMR}(75 \mathrm{MHz}$, DMSO) $\delta 182.28,182.25,147.47$, $147.44,135.31,133.43,132.73,130.90,126.44,126.23,125.84,125.67,114.50,100.73$. LCMS (ESI): $m / z 264.83$. 